\title{
The Effect of Tax Incentive on Domestic Investment in Ethiopia: ARDL Approach
}

\author{
Guesh Tesfamariam Tsehayu \\ Tigray Customs Bureau; Ethiopia \\ Weldeslasie Teklencheal Berhe \\ Ethiopian Civil Service University; Ethiopia
}

\begin{abstract}
The aim of this paper was to evaluate the effect of tax incentive for domestic private investment over the period 1982 to 2017. The study adopts quantitative method and descriptive design of research respectively. To this end, secondary data have been collected from pertinent government authorities and World Bank. Descriptive statistical analysis has been used to analyze the trends of domestic investment, tax revenue and tax incentive of Ethiopia. For analysis of inferential statistics of time series data Autoregressive distribution lag approach to co-integration and error correction model are applied to investigate the long-run and the short-run relationship between the dependent variable (domestic investment) and the explanatory variables. Due to adoption of tax incentives; there was an incremental trend of domestic investment in the study period, but has no consistent growth trend. In the long run tax incentives have a positive significant impact effect on domestic investment at five percent. A one percent change in tax incentive brought 1.401 percent change in domestic investment in Ethiopia. The finding implies domestic investment has been stimulated through tax incentives complemented with sustainable economic growth, basic infrastructures and social overheads and improved and globally inclusive market. The study basically recommends that the government of Ethiopia should approve implementation of critical and periodically costbenefit effective tax incentive with good access of market, basic infrastructure and sustainable economy to boost domestic investment.
\end{abstract}

Keywords: Tax Incentive, Domestic Investment, Ethiopia, ARDL

DOI: $10.7176 / \mathrm{RJFA} / 11-5-06$

Publication date:March $31^{\text {st }} 2020$

\section{Introduction}

Both developed and developing countries offer tax incentive to promote investment, however, the effect of tax incentive on investment, and determinants of investment is still a subject matter of considerable debate in economic theory and policy (UN, 2018 and Thabani, 2014). The scholarly debates about the set of policies needed to promote investment investigate of particular importance for developing countries have investigated the determinants of domestic investment in developing countries (Atukeren, 2005).

The main objective of investment incentives is for job creation, followed by technology transfer and export promotion, while the most important target industry is IT and business services, followed by agriculture and tourism (UNCTAD, 2014). Both developed and developing countries are trying to attract investment through various fiscal and non-fiscal incentives. The tax incentive is one of the fiscal incentives used by many countries to attract investors and increase investment in a country. One place to start thinking about tax incentives is to consider what role governments should play in encouraging growth and development (Easson and Zolt, 2002).

Tax revenues are necessary as a veritable tool of economic growth and development depends on a proper tax system which has the capacity to generate revenue through tax. While fulfilling the revenue function, taxes also have a pervasive influence on economic decisions of individuals and businesses, and on social equity (SADC, 2004). Developing countries use tax incentives to promote investment, but its effectiveness is controversial. The use of tax incentives may bring financial costs for the country. Not only financial costs such as foregone revenue and administrative costs but, if not carefully designed and implemented, also welfare costs through inefficient allocation of capital. Concerning the benefits, it is unclear to what extent tax incentives are effective in attracting investment (Klemm, 2010).

According to Proclamation No. 769/2012, the country Ethiopia offers different tax incentives to encourage and expand investment, increase inflow capital and speed up the transfer of technology into the country; to enhance and promote the equitable distribution of investments among regions, to attain transparency and efficiency of administration and benefit the society by ensuring competitiveness among investments made by investors.

\section{Statement of the Problem and Literature Review}

Majeed (2008) argued that countries with a high participation of investment succeeded in higher economic growth and made many economic and structural reformations to encourage as well as attract potential investment. Investment incentive from other has become most popular in the world, particularly in LDCs; however investment 
incentives mostly focus on economic performance objectives, lesson sustainable development. In addition, incentives are widely used by governments as a policy instrument for attracting investment, despite persistent criticism that they are economically inefficient and lead to misallocations of public funds (Blomstrom, 2003).

The implication of high investment levels is the productive capacity of the economy will consequently increase, which in turn, subsequently leads to higher rates of economic growth, job creation and opportunities for the poor to improve their livelihoods (Esubalew, 2014).

The tax incentive system plays an important role in the life of the society and development of the country; however the mere existence of tax incentives doesn't guarantee the effective growth of an economy; proper mobilization and use of this key input is indispensable, yet policies often fail to fully assess their likely costs and potential benefits.

There appear to be two perspectives regarding the effectiveness of fiscal incentives, some argue that fiscal incentives promote investment which generates job opportunities and leads to overall economic growth. On the other hand, those who advise against tax incentives argues tax preferences create inequity, actual revenue can be high if the investment has been viable anyway, and abusive tax avoidance schemes erode the revenue base (Bolnick, 2004).

Despite the aforementioned debate, Ethiopia, being one of developing economies has been undertaking tax reforms, introduces incentives and made amendment following the policies of the past governments in power. In the past decade following the general 1992 liberalization policy of the country, major series reforms have occurred. These are like deregulation, privatization, liberalization of the foreign exchange market, elimination of export tax except for raw hides \& skins, lowering of maximum import duties and the provision of adequate incentives.

The government has also been providing investment incentives to encourage investment and to promote the inflows of foreign capital. Reduced customs import duties, exemptions from payment of export customs duties, income tax holding, tax holidays and losses carried forward are some of the investment incentives given by Ethiopian government. However, there is no single study or document which assesses the benefits earned and what costs were incurred as a result.

Further, according to Esubalew (2014) proportion of domestic investment in Ethiopia 11.9

percent of GDP.On the other hand, as per Ethiopian Revenue and Customs Authority(ERCA) annual report shows that revenue forgone granted to investment was $51.07 \%$ of government revenue in 2014 and it's also growth remains steady that indicates huge amount loss of public resource not to finance the needs of society (ERCA, 2014). The paradox between low investment and huge forgone revenue needs further research to be conducted in the sector.

Investment is widely considered one of the main drivers of economic growth in the world because it is a flow that increases the existence of capital in the economy. This, particularly private investment, has already got credibility in ensuring sustainable economic growth and poverty alleviation. Designing appropriate strategies for catalyzing and stimulating investment in Africa requires a good understanding of the key determinants or drivers of investment in African countries (UNCTAD, 2014). To encourage domestic investment and attract different programs, tax incentive which is most popular has been introduced, but fails to assess its cost-benefit and its effectiveness remain debatable in developing countries.

The previous empirical studies focused on investment determinants considering the significant contribution of investment for achieving sustainable economic growth, there is little empirical analysis in the academic arena on determinants of domestic investment but fail to look the nexus between foreign direct investment and domestic investments; he uses a panel data to examine the determinants of domestic investment for some African countries but ignores the link between domestic investment foreign direct investment (Haile, 2013).

Further, even Esubalew (2014) investigated determinants of domestic investment in East Africa, including Ethiopia uses panel data and has analyzed the relationship domestic investment with foreign direct investment and public investment, but he failed to see the effect of tax incentive; regression analysis by Abdishu (2013) and Kurabachew (2016) have failed too. The effect of tax incentive on domestic investment in manufacturing only and did not examine the relationship among domestic investment and, public and foreign direct investment.

Therefore; researcher has attempted on conducting the effect of tax incentive on domestic investment Ethiopia from 1982-2017 which includes the determinants of domestic investment using ARDL approach of co integration.

\section{Methodology}

The appropriate research approach used for this study was quantitative research which has been performed by using both descriptive research design and econometric analyses. Quantitative research uses a standard format with a few minor, interdisciplinary differences of generating a hypothesis to be proved or disproved. This hypothesis must be checked by some mathematical and statistical means, and is the basis around which the entire research has been designed.

The researcher entirely relies on secondary data types which are annually time series covering from 19822017 regarding variables domestic investment as dependent variable and trade openness, inflation, investment, 
infrastructure, lending interest rate, growth rate of gross domestic product (GDP) and foreign direct investment (FDI) as explanatory variables.

The collected data has analyzed by using descriptive statistical analysis and econometrics. An econometric method of data analysis was used to determine the significance level of selected explanatory variables which determine the investment decision in Ethiopia. The empirical investigation has been carried out using auto regressive distributed lag (ARDL) model of ordinary least squares (OLS) estimation techniques by using Eviews 9.

Econometric analysis using Auto Regressive Distributive Lag (ARDL) model has been employed. Augmented Dickey Fuller test, bound test and other relevant tests have been conducted to examine unit root test and the relation between dependent variable domestic investment and explanatory variables. Econometrics can be used to test the compatibility of a theory, to measure unknown values of theoretically defined parameters or unobservable variables, to predict the value of a variable and characterize a relationship or phenomena (Hoover, 2006).

\section{Model Specification and Definition of Variables Specification of the Model}

The study follows the leads of the flexible accelerator theory of investment due to lack of adequate data of macroeconomic variables that enables to estimate invest function(Oshikoya, 1994) and (Ghura and Goodwin, 2000). According to Ayeni (2014) the accelerator theory because the variables of the accelerator theory, such as GDP growth, FDI (as percentage of GDP), inflation (annual percentage changes) and interest rates can be accessed adequately in comparison to other macroeconomic economic variables that affect investment.

The most commonly used model in examining the determinants of private investment in least developing countries is the flexible accelerator model. Hence, like previous studies such as Bakar (2011), and Mutenyo et al. (2010) and Thabani (2014), this study used a modified flexible accelerator model specifically with availability of data. The model used in the study can specify in the following which also had been used John (2012) general form as with modification:

$D I=\beta_{0}+\beta_{\mathrm{i}} X_{i}$ then also modified to include focus variable

$D I=\beta_{0}+\beta_{\mathrm{i}} X_{i}+\beta I N C E N T I V E_{\mathrm{i}}+\varepsilon$

Where; $D I=$ Domestic Investment

This function specifies Domestic investment as a function of the priority variable (incentives) and other control variables $(\mathrm{X})$. The model is modified to take special features of the country and theories into account. DI is the dependent variable measures domestic investment which is defined in real value. Given the difficulty of measuring tax incentives, this study used a dummy variable to show the presence and absence of tax incentives in sectors under consideration. It is assumed that:

Tax incentive takes a value of 1 if the incentives are offered and zero otherwise. Vector $\mathrm{X}_{\mathrm{i}}$ represents other variables which affect the flow of DI. These control variables are Market growth/size (real GDP growth rate), FDI, Openness of the economy, public investment and macroeconomic instability such as inflation, real interest rate. Though many variables have been proposed by literatures as determinants of DI it is not possible to include all of them. Due to this fact, we chose few of them depending on previous studies specific to a country, the strength of the variety and availability of data. $\varepsilon$ is an error term and $\beta_{0}$ is an intercept of system equations.

The empirical investigation has been carried out using auto regressive distributed lag (ARDL) approach to co-integration and error model. The model constructed in equation 3.2 developed with modification previous work and flexible accelerator model. This model in contrary to these incorporates PUB, FDI and DUMT.

$\mathrm{DI}=\mathrm{f}(\mathrm{GDP}$ growth (GDPGR), Foreign direct investment (FDI), Inflation (INF), Market openness (OPEN), lending interest rate (LER), and Public investment (PUB). The researcher included one dummy variable of tax incentives as focus dummy variables of the study and it is represented by (DUMT). The model to be estimated is therefore:

$\mathrm{DI}=\mathrm{f}(\mathrm{GDPGR}, \mathrm{INF}, \mathrm{FDI}, \mathrm{MOP}, \mathrm{PUB}, \mathrm{LR}, \mathrm{DUMT})$

Where,

DI-operational domestic investment inflow in real value based on 2000 constant price

FDI-operational foreign direct investment based on 2000 constant price

GDPGR-real gross domestic product growth rate

INF-Inflation based on consumer price index

OPEN-Market/Trade openness (Imp +Expo

/GDP) LER- lending interest rate in annual \%

PUB- Public Investment based on 2000 constant price

DUMT $=$ Dummy variable for tax incentives.

Unlike mathematical model, econometric model is not exact, but it is stochastic. A stochastic model(for any given value $\mathrm{X}$, the independent variable $\mathrm{Y}$ assumes some specific value only with some probability) is a model in 
which the dependent variable is not only determined by the explanatory variables included in the model, but also by other variables which are not included in the model. In order to take into account those omitted variables in the model, it is important to introduce a random variable in the above function which is usually denoted by the letter , $\mathrm{u}^{\mathrm{ee}}$ is called error term or random disturbance term or stochastic term of the model, which is a surrogate measure for omitted variables from the model.. By introducing this random variable in the function, the extended model will be:

$\mathrm{DI}_{\mathrm{t}}=\left(\beta \mathrm{o}+\beta_{1} \mathrm{GDPGR}_{\mathrm{t}}+\beta_{2} \mathrm{INF}_{\mathrm{t}}+\beta_{3} \mathrm{OPEN}_{\mathrm{t}}+\beta_{4} \mathrm{LER}_{\mathrm{t}}+\beta_{5} \mathrm{FDI}_{\mathrm{t}}+\beta_{6} \mathrm{PUB}_{\mathrm{t}}+\beta_{7} \mathrm{DUMT}+\mathrm{u}_{\mathrm{t}}\right.$

$\beta 0=$ is an intercept of the model (constant term); $\beta_{1}, \beta_{2}, \beta_{3}, \beta_{4}, \beta_{5}, \beta_{6}$ and $\beta_{7}$ are estimate coefficients of GDPGR, INF, OPEN, LER, FDI, PUB, and DUMT respectively. All the Variables are converted into a logarithm form before estimation to reduce problems of hetroscedasticity and percentages(elasticties) approaches. Using log the model to be estimated can be specified as follows;

$\mathrm{LGDI}_{\mathrm{t}}=\beta \mathrm{o}+\beta_{1} \mathrm{LGDPGR}_{\mathrm{t}}+\beta_{2} \mathrm{LGINF}_{\mathrm{t}}+\beta_{3} \mathrm{LGOPEN}_{\mathrm{t}}+\beta_{4} \mathrm{LGPUB}_{\mathrm{t}}+\beta_{5} \mathrm{LGFDI}_{\mathrm{t}}+\beta_{6} \mathrm{LGLER}_{\mathrm{t}}+\beta_{7} \mathrm{DU}$ MT $+\mathrm{u}_{\mathrm{t}} \quad$ (3.4). Where, $\beta$ o is the constant term, $\beta_{1}-\beta_{7}$ are estimates coefficients and $u_{t}$ is an error term with zero mean and constant variance covariance. To keep the data set consistent, over th 36 years spanning from 1982 to 2017 has been used for statistical analysis.

\section{Variable Description and Expected Sign}

The description and expected signs of the dependent and explanatory variables that are included in the model are explained under real value based on 2000 constant price valuation.

Table 3.1: Summary of Variables under Investigation and Expected Signs (in log form)

\begin{tabular}{|c|c|c|}
\hline $\begin{array}{l}\text { Explanatory } \\
\text { Variables }\end{array}$ & Description of indicator variable & $\begin{array}{l}\text { Expecte d } \\
\text { sign }\end{array}$ \\
\hline $\begin{array}{l}\text { GDP growth rate in } \\
\text { logged (LGGDP) }\end{array}$ & $\begin{array}{l}\text { An indication of real output growth rates of economy of countries. In } \\
\text { neoclassical theory of investment, there is a positive association between } \\
\text { private investment and income growth rate. }\end{array}$ & + \\
\hline $\begin{array}{l}\text { Inflation: } \\
\text { and } \\
\text { (LGINF) }\end{array}$ & $\begin{array}{l}\text {-Variables used to capture macroeconomic instability and price system of } \\
\text { information content. Signifies an explicit evidence of country seconomic } \\
\text { instability and acts as a deterrent for private investment inflow. } \\
\text {-Higher expected inflation lowers the real interest rate, causing portfolio } \\
\text { adjustments away from real money balances to real capital thereby raising } \\
\text { real investment }\end{array}$ & $-/+$ \\
\hline $\begin{array}{l}\text { Lending Rate } \\
\text { (Annual \% \& in log } \\
\text { form) (LGLER) }\end{array}$ & $\begin{array}{l}\text { An indication of the user cost of capital goods (when it rises, cost of capital } \\
\text { good increases and investment declines, in line with neoclassical } \\
\text { assumption. }\end{array}$ & - \\
\hline $\begin{array}{l}\text { Market Openness to } \\
\text { Trade in log } \\
\text { (LGOPEN) }\end{array}$ & $\begin{array}{l}\text { The extent to which countries allow international trade with others to obtain } \\
\text { funds from other economies and invest its surplus to other countries. } \\
\text { Expressed by ratio import-export to GDP. } \\
\text { Higher ratio represents more openness and high integration of the economy } \\
\text { to global. }\end{array}$ & + \\
\hline FDI in $\log (\mathrm{LGFDI})$ & $\begin{array}{l}\text { Investment activity captured by inflows of foreign investors into the } \\
\text { economy can crowd in or crowd out effect on domestic private investment }\end{array}$ & $+/-$ \\
\hline $\begin{array}{l}\text { Public investment } \\
\text { in } \log (\text { LGPB) }\end{array}$ & $\begin{array}{l}\text { Investment activities of the government on private investment may } \\
\text { crowd in or crowding out. }\end{array}$ & $+/-$ \\
\hline $\begin{array}{l}\text { Tax incentive } \\
\text { (DUMT) }\end{array}$ & $\begin{array}{l}\text { A tax incentive is a special tax provision granted to qualified investment } \\
\text { projects that have the effect of lowering the effective tax burden. Tax } \\
\text { incentives, lower the costs related to investment. On the other hand the } \\
\text { opportunity cost of those incentives is higher } \\
\text { than the additional investments created. lor } 0 \text { for the presence(since 1992) } \\
\text { or absence(before 1992) of tax incentive. }\end{array}$ & $+/-$ \\
\hline
\end{tabular}

Source: Own Compiled Based on Literature, 2018

\section{OLS Assumptions and Econometrics Criteria of Evaluation}

The regression analysis is to examine two things. First, how does a set of predictor variables do good job in predicting the dependent variable? Second, which variables in particular are significant predictors of the dependent variable and the magnitude and sign of beta estimates?

Regression analysis is concerned with the study of the dependence of one variable; the dependent variable, on one or more other variables, the explanatory variables, with a view to estimating and/or predicting the (population) mean or average value of the former in terms of the known or fixed (in repeated sampling) values of the latter (Gujarati, 2004). 
The basic framework of regression analysis is the classical linear regression model (CLRM).This is based on a set of assumptions that may be unrealistic, in that the least square estimators take on certain properties summarized in the Gauss-Markov theorem. It states that in the class of linear unbiased estimators, the least square estimators have minimum variance. In short, these properties are said to be BLUE, i.e. Best, Linear, Unbiased, Estimators. This is to indicate that Least Square (LS); estimation techniques and hypothesis testing could be conducted validly and LS estimation to be BLUE.

Table 3.2: Tests of time series data

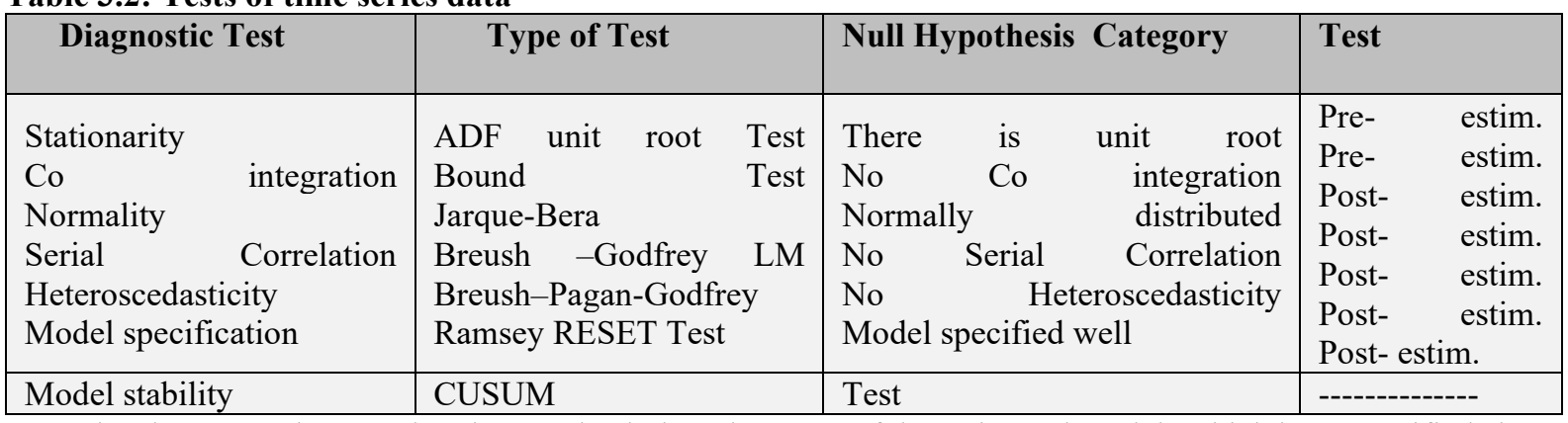

The above tests have undertaken to check the robustness of the estimated models which have specified above but test of multicolinearity left out because it is soundless test in lagged same variable of time series data as well as finally data results, interpretation and finding have summarized accordingly. To check a structural breakpoint over the study period graphical stability diagnostics tests has been tested by applying the cumulative sum of recursive residuals (CUSUM) and the cumulative sum of squares of recursive residuals (CUSUMSQ) test. These stability tests have recommended by Pesaran and Shin $(1999,2001)$. Model stability test using cumulative sum of recursive residuals (CUSUM test) could be replaced for Chow test of structural breakpoint.

\section{Result and Discussion}

Fig. 4.1 shows that investment has demolished due to nationalization and restriction policy of Derge from 19821991 in which private sector was severely restricted from the country's economic activity participation. Thus, the growth of domestic investment has been sluggish until 1991 and its development might have been adversely affected by political and macroeconomic instabilities while openness and liberalization, growing income and infrastructural facilities seem influenced them positively.

Figure 4.1: Trends of gross investment over 1982-2017 as percentage share of GDP

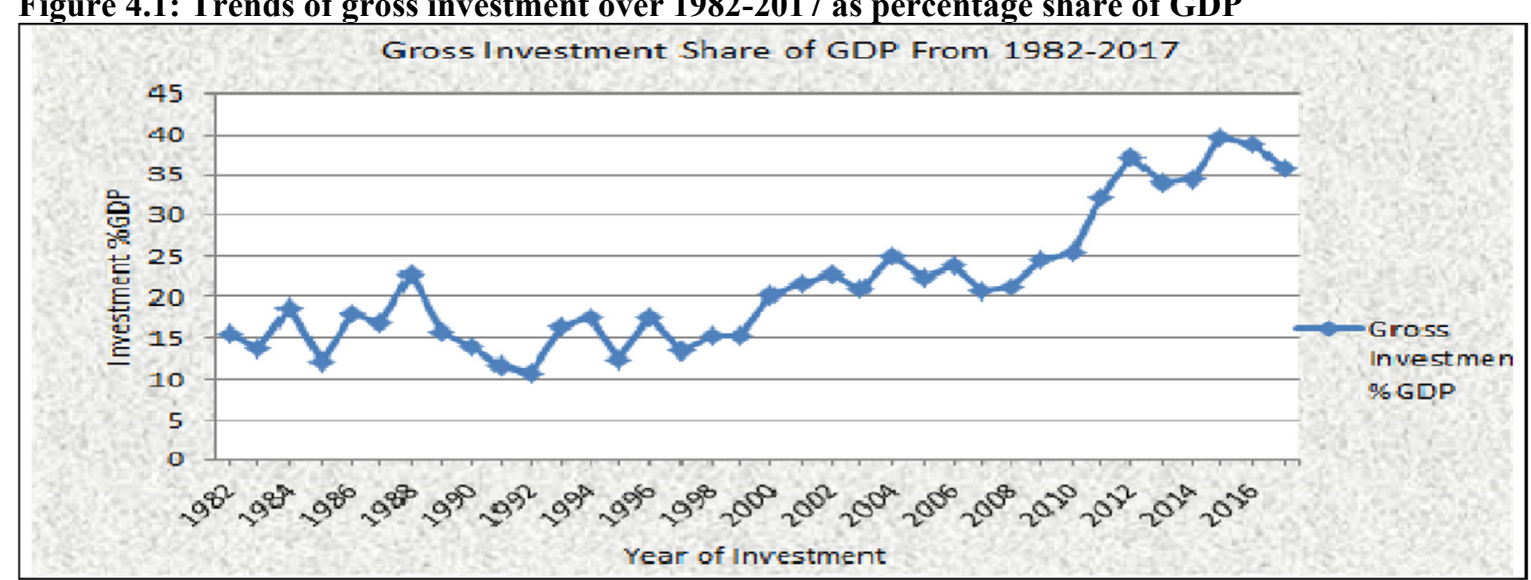

Source: IMF/World Bank Macro Data, 2018

Fig. 4.3 below implies that government revenue forgone granted to promote investment has no consistency and has failed in its intended goal. These may be due to a loophole in investment and tax law, low monitoring and supervision system, implementation, problem (abuse of tax incentive privilege) which leads distortion of the market operation system and rent seeking. Since the trend of the granted tax incentives and the operational investment shows neither similar, nor regular pattern, the up and down trend of operational investment and revenue have forgone depicts the role played by the non-tax investment incentive. 


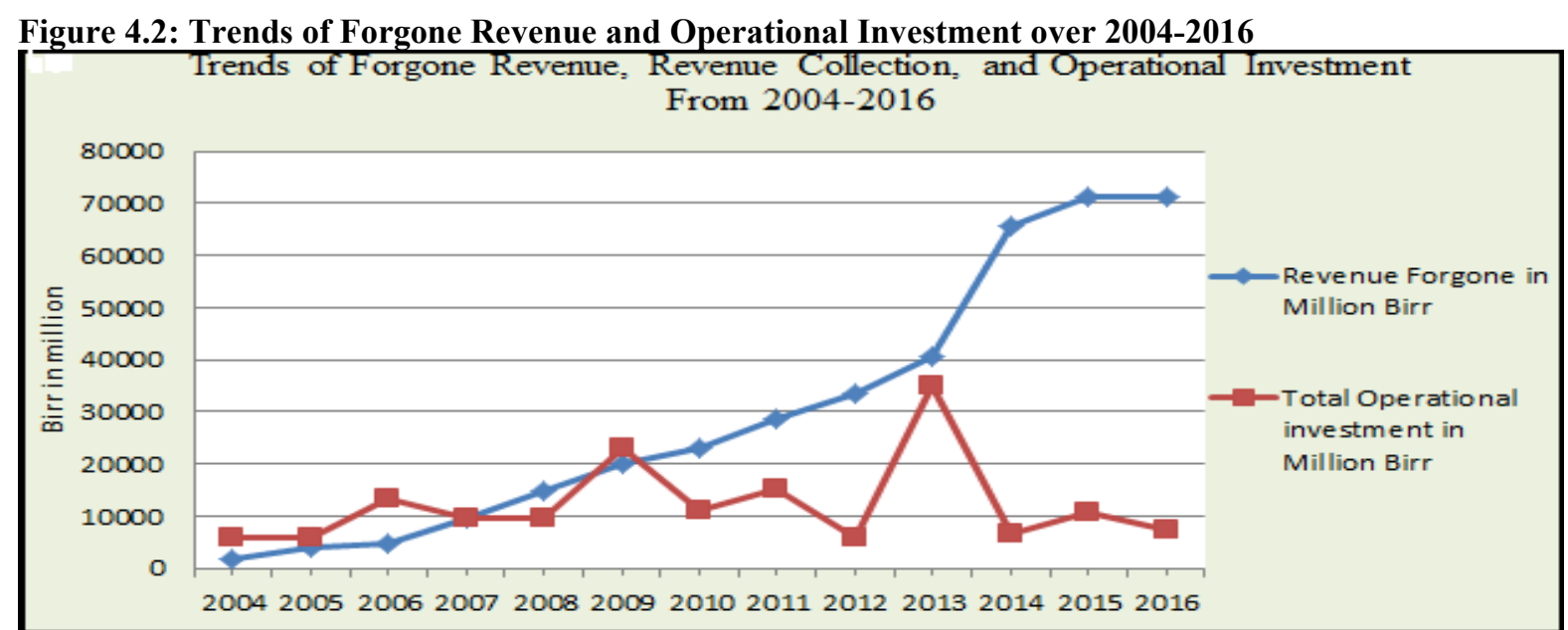

Source: EIC, ERCA, 2018

The optimal lag length of the variable is determined by using Akaike Information Criteria (AIC) which has taken at lag 3. The null hypothesis in the Augmented Dickey- Fuller test is that the underlying process which generated the time series is non-stationary.i.e: Null Hypothesis, $\mathrm{H}_{\mathrm{O}}$ : There is unit root, $\mathrm{H}_{1}$ : There is no unit root. A variable is stationary if the absolute term ADF statistic is greater than the absolute term of critical value for rejection of the null hypothesis for unit root. Otherwise it is non-stationary (Gujarati, 2004).

Table 4.3 shows that DI has got its stationarity at the level of integration with both intercept and with trend it is stationary as I(0). GDP growth in the order of integration, equal to 0 or $\mathrm{I}(0)$ is stationary at the level of with intercept at lag 0 , and with intercept and the trend at lag 0 . Foreign direct investments are stationary at first difference of with intercept and with the trend and intercept at lag 0 . A proxy variable of trade openness is stationary at the order of integration 1 or I (1) without trend and intercept at lag 0 .

Table 4.3: Augmented Dicky-Fuller: Unit Root Test

\begin{tabular}{|c|c|c|c|c|c|c|}
\hline \multirow{2}{*}{$\begin{array}{l}\text { Variable } \\
\text { name }\end{array}$} & \multicolumn{3}{|c|}{ Without trend(only intercept) } & \multicolumn{3}{|c|}{ With trend and intercept } \\
\hline & Level & $\begin{array}{l}\text { 1rst } \\
\text { difference }\end{array}$ & $\begin{array}{l}\text { Order of } \\
\text { integration }\end{array}$ & Level & $\begin{array}{l}1^{\text {rst differenc }} \\
\text { e level }\end{array}$ & $\begin{array}{l}\text { Order of } \\
\text { integration }\end{array}$ \\
\hline Lodi & $-4.273125^{*}$ & & At I(0) $1 \%$ & $-5.198324 *$ & & At I $(0) 1 \%$ \\
\hline Lgfdi & -1.751215 & $-6.414048 *$ & At $(1) 1 \%$ & -0.273407 & $-6.55451 *$ & At I(1) $1 \%$ \\
\hline Lggdp & $-4.307151^{*}$ & & AtI $(0) 1 \%$ & $-4.570086^{*}$ & & At I $(0) 1 \%$ \\
\hline Lginf & $-3.455380 * *$ & & $\operatorname{AtI}(0) 5 \%$ & $-5.467548 *$ & & At I $(0) 1 \%$ \\
\hline Lgler & -1.870870 & $-6.145335^{*}$ & At I $(0) 1 \%$ & -2.264586 & -6.048438 & At (1) $1 \%$ \\
\hline Lgopen & $-0 / 983701$ & $-5.056044 *$ & At I(1) $1 \%$ & -1.210994 & -5.008219 & At $(1) 1 \%$ \\
\hline Lgpub & $-4.048898 *$ & & At I $(0) 1 \%$ & $-5.487548 *$ & & At I $(0) 1 \%$ \\
\hline \multicolumn{2}{|c|}{ Critical Values } & $\begin{array}{r}\text { ept, no trend } \\
-3.639 \\
-2.951 \\
-2.614 \\
\end{array}$ & & \multicolumn{2}{|c|}{ Test Critical Values $1 \%$} & $\begin{array}{l}-4.25288 \\
-3.54428 \\
-3.20470 \\
\end{array}$ \\
\hline
\end{tabular}

Source: Author's Calculation using Eviews 9, 2018. Note: The *, ** indicates rejection of the null hypothesis of non-stationary and critical value at $1 \%$ and $5 \%$ significance level based on Mackinnon(1996) critical value respectively.

The long run Ethiopia's domestic investment model has been selected and reported in table 4.4 below; that the coefficient of determination denoted by $\mathrm{R}^{2}$ is 0.9984 that is about $99.84 \%$ of the variation in domestic investment is explained by the variation in the explanatory variables. In addition, the F-statistic is 41.815 with pvalue 0.023613 is quite robust at the one percent level of significance. Since dependent variable domestic investment and all repressors are specified in the log-linear form, the coefficient of these independent variables can be interpreted as elasticity with respect to a dependent variable (domestic investment).

In the long run, holding other things constant, a one percent change in foreign direct investment (FDI) brought a 0.96971 percent decrease in domestic investment. This finding implies that FDI has is crowding out effect (displaces) on domestic investment which is not desirable for the development of Ethiopia. In fact, the common belief is that FDI complements domestic investment because foreign firms are associated with better technology that may spill over to domestic investment. However, in this study presents, FDI in Ethiopia lowers domestic firm ${ }^{e}$ s productivity using different prospects realizing technological gaps between domestic and foreign firms. Thus, with better and advanced technology leads to control the market and crowds out domestic investors 
(Esubalew, 2104). Generally, developing countries experience negative spillover effect while developed countries experience positive spillover effect; and many developing countries experience negative spillovers from FDI because of the wider technological gap that exists between foreign firms and the domestic firms (Mutenyo et al. 2010).

The variable GDP growth proxy of measure of market size/growth is significant with p-value 0.0463 at the $5 \%$ level of significance and coefficient is 0.173090 with an expected positive sign, thus, lending credence to accelerate the principle effect. Growth rate real output promotes investment because it indicates changes in aggregate demand for output that investors seek to meet. The findings confirm to some previous studies. Frimpong and Marbuah (2010), Esubalew (2014) among other studies. So, in the long run, keeping other things constant, a one percent change in gross domestic product brought a 0.173090 percent increase in operational domestic investment. It also creates consistent with expectations of neoclassical investment theory, positive association between investment and income growth.

In this study, inflation has found insignificant at 5\%, but significant, with $10 \%$ and with an expected negative sign. At 10\%, this has found to be significant and was confirmed by Kassahun, (2010) represented by its current, inflation is estimated to have a negative influence on the growth of investment that a 1 percent increase in the rate of inflation inflicts the growth of domestic investment decreased by 0.310944 percent. And this finding confirmed with neo-classical (Keynesian) theory in which rise in interest rate increases cost capital goods that constrained investment which in turn leads to a lower rate of investment. Thus, in the long run, the lending interest rate has an adverse effect, but insignificant on domestic private investment. This has confirmed to the finding of Esubalew (2014) in East Africa adverse effect of interest rate on domestic private investment due to its underdevelopment and financial repression.

Trade openness has a positive sign and significant relationship with domestic investment. The probability value of t-statistics for openness is 0.0062 which is below both 5 and 1 percent level of significance. The coefficient of market openness which is measured as a log of the ratio of import-export with real GDP is positive and statistically significant at both $1 \%$ and $5 \%$ means the more open the market system is the higher the Domestic investment holding other factors constant. The positive sign is as per our expectation and it is due to the open market policy of the Ethiopian government, which creates trade opportunities for the domestic investors. This result is the same as Guadagno (2012) and Kassahun (2010); the higher the import-export rates of a country the greater the market opportunity or trade openness for investors.

Tax incentives have been used by governments as tools to promote a particular economic goal. Investment tax incentives are used both to encourage capital accumulation in the long run and to stimulate economic activity in the short run. In case of this study the dummy variable for investment (and change tax) policy, particularly tax incentive policy, which is the main focus of the study, turns out to great improvement in investment with a coefficient 1.4009 and p-value 0.0183 which is significant with a positive coefficient. This can be due to tax policy change from Dereg to EPRDF helped grow on average by $1.401 \%$ per year in domestic private investment at $5 \%$ level significance. This result is consistent with Van Parys and Klemm (2011), James (2009) and UN (2018). The positive sign here agrees with the assumption that the lower tax rate means lower cost burden and higher profit after tax for investors. Regardless, only those tax incentive programs that can pass cost-benefit assessments of both economic and revenue impacts are worth attempting or preserving.

In general, GDP growth, trade openness, public investment and tax incentive dummy have a positive and significant, whereas FDI is negative and significant while LER and Inflation are negative but insignificant determinants of domestic operational investment in the long run. And the strength of variables' effect on domestic investment market openness has a strong positive effect while tax incentive has a strong positive significant effect next to trade openness, however, FDI and LER have negative with proportional strong effect on domestic effect on domestic investment. This confirms with the result of Tanzi (2000) and Zee, (2002) in which tax incentives can promote investment, but they are not the "first best" solution as overall economic and institutional environment may be more important for a success of projects. Finally, the estimated long-run model presented as follows with figures in the parenthesis indicates the p-value.

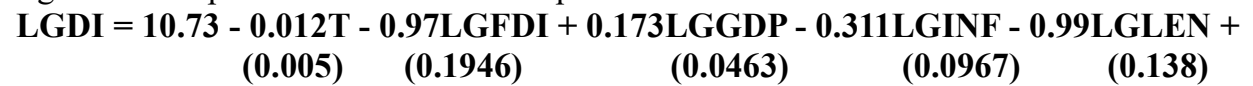

2.16LGOP +0.17LGPUB

+ 1.40DUMT (0.002)

(0.00) (0.02) 
Table 4.4: Estimated Long-run Coefficients Using ARDL Approach

Dependent Variable: LGDI

Selected Model: ARDL(2, 3, 3, 3, 3, 2, 3, 3) Based on AIC

Regressors

LGFDI

LGGDP

LGINF

LGLEN

LGOPEN

LGPUB

Tax incentive DUMT

$\mathrm{C}$

@)TREND

R-squa. 0.998408 Adjusted R-

Coefficient

$-0.969371$

0.173090

$-0.310944$

$-0.988476$

2.159902

0.169182

1.400954

10.724456

$-0.012085$

squ 0.974531

Source: Author's calculation, 2018 Using Eviews 9

Note: **, * indicates five and one percent level of significance

The graphical stability tests used not only identifying their significance but also it tells us at what point of time a possible structural break (instability) has occurred. Here, model stability test using cumulative sum of recursive residuals (CUSUM) could be replaced for Chow test structural breakpoint. If the plot of CUSUM / CUSUMSQ statistic moves between the critical bounds/red lines (at 5 percent significance level), then the estimated coefficients or the model/system are/is said to be stable in the long run / short run. Figure 4.3 and 4.4 reported that the plot of CUSUM and CUSUMSQ test did not cross the lower and upper red lines critical limits which indicated that, the estimate is stable and there is no any structural break in the long run respectively.

\section{Fig 4.3.The Plot of the Cumulative Sum of Recursive Residuals}

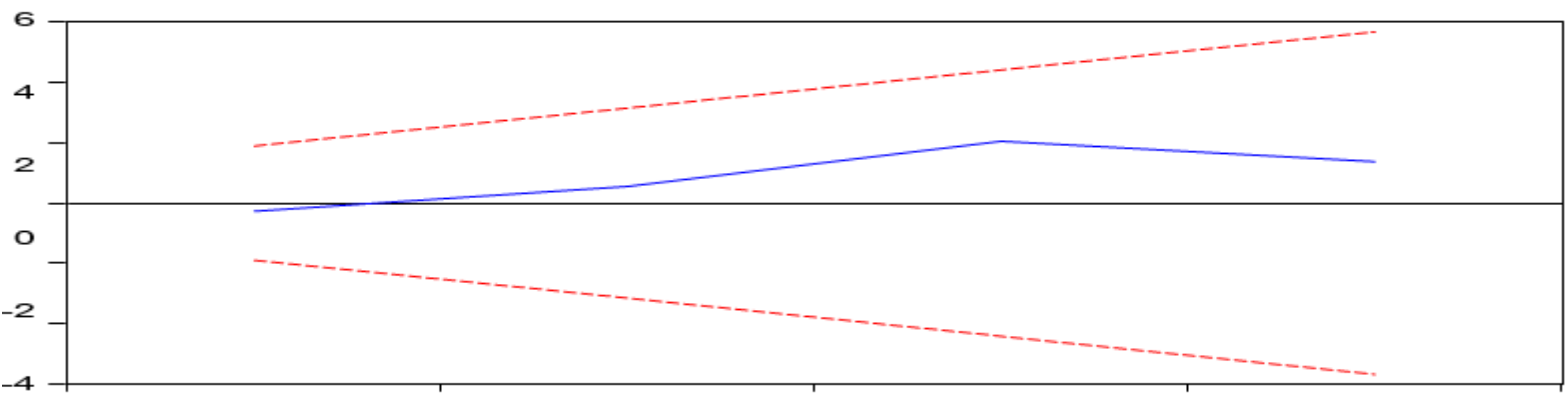

$-6$

2014

2015

2016

2017

Source: Computed by the Author, 2018 using Eviews 9

Fig 4.4. The Plot of the Cumulative Sum of Squares of Recursive Residuals

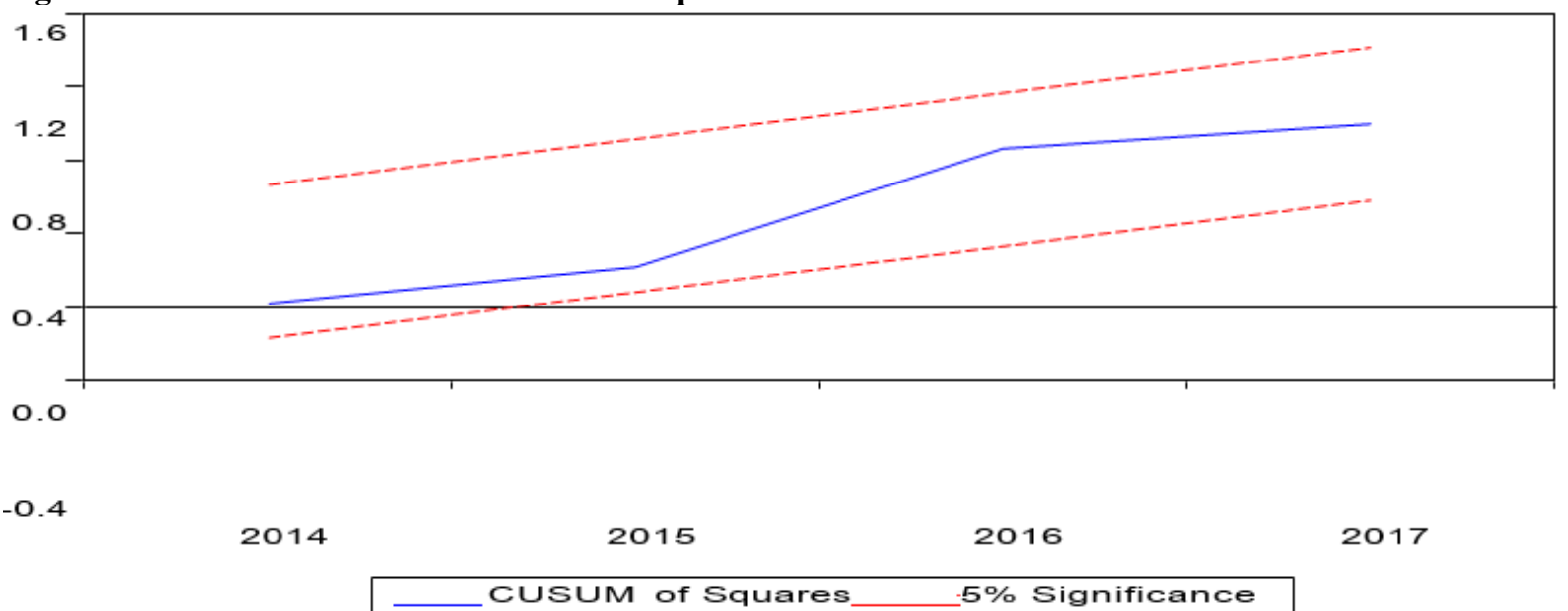

Source: Author Calculations, 2018 using Eviews 9 


\section{Short run Error Correction Model (Estimates)}

After the acceptance of long-run coefficients of the growth equation, the short run ECM models estimated. The speed of adjustment denoted by $\operatorname{ECM}(-1)$ is a one period lagged residual obtained from the estimated dynamic model.

Where: $\quad \operatorname{ECM}(-1)=$ LGDI - $(-0.9694 *$ LGFDI + 0.1731*LGGDP- 0.3109*LGINF -0.9885*LGLEN

$$
+2.1599 * \text { LGOP+0.1692*LGPUB } \quad+1.4010 * \text { DUMT } \quad+
$$

Moreover, it should have a negative sign and statistically significant at a standard significant level (5\%). According the above table 4.5 in the short run model, the coefficient of determination denoted by R2 is 0.7336 that about $73.36 \%$ of the variation in domestic investment is explained by the variation in the explanatory variables in the short run. In addition, the F-statistic is 2.79 and quite robust at the five percent level of significance. The equilibrium error correction coefficient estimated 0.741509 is highly significant with p- value 0.0081 and has the correct negative sign which implies that a very high speed of adjustment to equilibrium after a shock.

The whole system is getting adjusted at the speed of $74.15 \%$ towards long-run equilibrium. Such highly significant error term is another proof for the existence of a stable, long-run relationship among the variables (Kidanemariam, 2013). The larger the error correction coefficient (in absolute value) the faster will be the economy's return to its equilibrium, after an exogenous shock.

The estimated short-run model reveals that FDI has a significant, but unlike long run, positive impact on domestic private investment with coefficient is 0.451075 with p-value 0.0334 . This finding implies that FDI has been crowding in effect (encourages) on domestic investment which is favorable for the development of Ethiopia in the short run. In fact, the common belief is that FDI complements domestic investment because foreign firms are associated with better technology and management skill that may spill over to domestic investment in the short run. GDP growth has expected positive effect and unlike long run significant that as real GDP growth increases across time by one percent, it raises domestic investment by 0.696182 percent this is the "accelerator effect".

Inflation has a negative and significant impact on domestic investment which leaves a negative impact on the long-term investment prospects and causes for the deterioration of purchasing power of money, less space to save money in the bank and unable to finance for investment project opportunities.

Tax incentive has negative and significant short-run effect on domestic investment. This had led to a huge amount of revenue loss without societal benefit and needs for paying attention to productivity and innovation with the well- designed incentive program and strong administration organ along with periodic assessment in the short run.

Table 4.5: Error Correction Model (Estimate)

Dependent Variable: D (LGDI)

\begin{tabular}{|c|c|c|c|c|}
\hline Variable & Coefficient & Std. Error & $\mathrm{t}$-Statistic & Prob. \\
\hline D(LOGFDI) & 0.451075 & 0.189704 & 2.377783 & $0.0334 * *$ \\
\hline D(LOGGDP) & 0.696182 & 0.252555 & 2.756560 & $0.0163 * *$ \\
\hline D(LOGINF) & -0.472975 & 0.173155 & -2.731507 & $0.0171 * *$ \\
\hline D(LOGLER) & 1.281723 & 0.527237 & 2.431018 & $0.0322 *$ \\
\hline D(LOGOPEN) & 2.554841 & 0.893894 & 2.858103 & $0.0134 * *$ \\
\hline D(LOGPUB) & 0.032243 & 0.033162 & 0.972288 & 0.3487 \\
\hline D(LOGDI(-1)) & 0.124208 & 0.217352 & 0.571462 & 0.5774 \\
\hline D(LOGFDI(-3)) & 1.028201 & 0.301596 & 3.409205 & $0.0047 *$ \\
\hline D(LOGGDP(-1)) & -0.172962 & 0.220175 & -0.785565 & 0.4462 \\
\hline D(LOGINF(-2)) & -0.732107 & 0.259307 & -2.823322 & $0.0144 * *$ \\
\hline D(LOGLER(-2)) & 1.513735 & 1.058701 & 1.429804 & 0.1937 \\
\hline D(LOGLER(-3)) & 2.464592 & 1.013133 & 2.432644 & $0.0302 * *$ \\
\hline D(LOGOPEN(-2)) & -1.126260 & 0.892115 & -1.262460 & 0.2290 \\
\hline D(LOGPUB(-2)) & -0.483113 & 0.209356 & -2.307615 & $0.0312 * *$ \\
\hline Tax incentive DUMT & -2.782764 & 0.756469 & -3.678621 & $0.0028 *$ \\
\hline $\mathrm{C}$ & 2.210225 & 1.812277 & 1.219584 & 0.2443 \\
\hline @TREND & 0.096580 & 0.043939 & 2.198028 & $0.0167 * *$ \\
\hline ECT(-1) & -0.741509 & 0.203652 & -3.641059 & $0.0081 * *$ \\
\hline R-squared & 0.733078 & \multirow{4}{*}{\multicolumn{2}{|c|}{ Durbin-Watson stat }} & \multirow{4}{*}{2.116073} \\
\hline Adjusted R-squared & 0.650567 & & & \\
\hline F-statistic & 2.793512 & & & \\
\hline Prob(F-statistic) & 0.032311 & & & \\
\hline
\end{tabular}

Selected Model $(2,3,2,2,3,2,2,1)$ based on AIC 


\section{CONCLUSION AND RECOMMENDATION \\ Conclusion}

Investment has been recognized as a facilitator of economic growth for developing countries as a result, the government of Ethiopian has introduced investment incentives (tax incentives) since 1992 to promote domestic investment and attract FDI. The study on trend of investment and tax incentive indicates that there is an inconsistent relationship between investment and tax incentive in which their trend shows neither similar, nor regular pattern. This merely indicates the existence of other powerful investment determining factor. Thus, the provision of the tax incentive scheme to attract investment was not the only factor that boosts investment rather harmonization of tax incentive with other non-tax determinants are more effective in persuading investors in favor of making more participation in the economy. In the study period, tax incentives and government revenue not balanced and revenue generation has remained ineffective due to tax-base erosion effect, but didn't yet get attention.

Based on the empirical analysis result of long-run ARDL model, it can be concluded that the hypothesis is consistent with the theory and tax incentive in short run and the long run of the model was found to be determining factor which confirms with the intention of governments towards fiscal policies. Though providing duty and tax incentives in the short run has a negative impact on revenue, productivity, in the long run, it has a positive impact on increasing domestic investment thereby revenue productivity as well as sustainable economic growth. Based on the long run ARDL model output, a one percent change in tax incentive, leads 1.401 percent change in domestic investment, given that other remains constant.

Further, other determinant factors of domestic investment are, GDP growth, trade openness and public investment have a positive and significant, whereas FDI is negatively significant. On the other hand, FDI has to crowd out effect on domestic investment which indicates that the existence of a very wide technological gap compared to that of the developed countries, making it difficult for domestic firms to realize the technology transfer in the form of spillover effects, and the sustainability of any country's economic development hinges on the growth of local entrepreneurs. The whole system is getting adjusted at the speed of $74.15 \%$ towards the long-run equilibrium

\section{Recommendation}

Provision of tax incentives to attract investment was not the first best solution to boost investment growth. Hence, the government should design or reforming program with priority, giving to non-tax incentive determinant which motivate investors to be active participants in the economy and with consistent growth. The government should bear in mind the necessary conditions when giving tax incentives: making sure that the incentive is transparent and the cost of its implementation; identifying taxpayers who benefit from the incentive; analyzing how effective the benefit is and making sure it is not harmful to the entire system. Policy makers should come up with good policies that suit Ethiopia's investment climate and to minimize the adverse effects of crowding out of FDI. A country should favour off FDI that does not displace domestic firms or FDI that promotes linkages with local producers. The linkage may be in the form of: technology transfer, supply contracts, training for labour and skill upgrading.

Governments should regularly prepare tax expenditure statements to measure and monitor the costs of tax incentives through international popular measures. In addition, incentive policies should be reviewed periodically to assess their effectiveness in helping to meet desired goals. To upgrade the poor data availability of tax incentives, the government must seriously take and organize a task force which can collect analyses, verified and organized these important data that are very obliging for a government decision, for policy and research input. Regarding the success of tax incentive programme on stimulating investment thereby economic development, government should: be clearly set forth intended objectives; crafted the type to best fit the objective; estimate the anticipated costs and benefits.

\section{References}

Abdishu, H., 2013. Factors Determining Private Investment in Ethiopia (Doctoral dissertation).

Asante, Y., 2000. Determinants of Private Investment Behaviour in Ghana.African Economic Research Consortium, Nairobi

Atukeren, E., 2005. Interactions between public and private investment: Evidence from developing countries. Kyklos, 58(3), pp.307-330.

Ayeni, T., M., 2014. The Impact of Tax Incentive on Private Investment:In Case of Manufacturing,(Thesis Unpublished, Ethiopian Civil Service University)

Bakare, A.S., 2011. The determinants of private domestic investment in Nigeria. Far East Journal of Psychology and Business, 4(3), pp.27-37.

Blomström, M., Kokko, A. and Mucchielli, J.L., 2003. The economics of foreign direct investment incentives. In Foreign direct investment in the real and financial sector of industrial countries (pp. 37-60). Springer, Berlin, Heidelberg. 
Bolnick, B., 2004. Effectiveness and Economic Impact of Tax Incentives in the SADC Region. Prepared by Nathan Associates for USAID under the SADC-TIFI Project.

Easson and Eric M. Zolt, 2002. Tax incentives, World Bank Institute, available at http://sitreresources, World Bank, org/INTTPA/resources/Easson Zolt paper.

ERCA,2014 : Ethiopian Customs and Revenues Authority, Ethiopia: Foreign trade and federal duty and tax revenue collection. Statistical Bulletin Vol.1, Addis Abeba Ethiopia.

Esubalew.T., 2014. An Investigation of Macroeconomic Determinants of Domestic Private Investment.

Frimpong, J.M. and Marbuah, G., 2010. The determinants of private sector investment in Ghana: An ARDL approach. European Journal of Social Sciences, 15(2), pp.250-261.

Ghura, D. and Goodwin, B., 2000. Determinants of private investment: a cross-regional empirical investigation. Applied Economics, 32(14), pp.1819-1829.

Guadagno,F., 2012. The determinants of industrialization in developing countries 1960- 2005,mimeo,UNUMERIT \&Maastricht Univerisity,p.26.

Gujarati, D.N., 2004. Basic econometrics. Tata McGraw-Hill Education.

Haile, G.A. and Assefa, H., 2013. Determinants of Foreign Direct Investment in Ethiopia: A time-series analysis.

Hoover, K.D., 2006. The Methodology Of Econometrics.

James, S., 2009. Tax and non-tax incentives and investments: evidence and policy implications. Investment climate advisory service of world bank group.

John, M.B., 2012. Determinants of Domestic Private Investment in Sub-Saharan African (SSA) Countries: The Role of Foreign Direct Investment.

Kassahun, S.A.M.U.E.L., 2016. The Impacts of Tax Incentives in Attracting Foreign Direct Investement in Ethiopia (Doctoral dissertation, Addis Ababa University Addis Ababa, Ethiopia).

Kidanemariam G., 2015. The Impact of Human Capital Development on Economic Growth in Ethiopia: Evidence from ARDL Approach to Co-Integration. Bahir Dar Journal of Education, 16(1).

Klemm, A., 2010. Causes, benefits, and risks of business tax incentives. International Tax and Public Finance, 17(3), pp.315-336.

Kurabachew, M ., 2016. Public and Private Investment Analysis in Ethiopia, Economics in Punjabi University, PatialaVolume: 04, Number: 06, International Journal Research Publication ISSN 2251, 1555 p 26-38 April, 2015.

Majeed, Muhammad Tariq and Khan, Saniya, 2008. "The Determinants of Private Investment and the Relationship between Public and private Investment in Pakistan NUST Journal of Business and Economics, Vol. 1, No. 1 (pp 41-48).

Mutenyo, J., Asmah, E. and Kalio, A., 2010. Does foreign direct investment crowd-out domestic private investment in Sub-Saharan Africa. The African Finance Journal, 12(1), pp.27-52.

National tax journal, pp.299-322.

Oshikoya R 1994. Financial Determinants of Domestic Investment in Sub-Saharan Africa;

Oshikoya, T.W., 1994. Macroeconomic determinants of domestic private investment in Africa: An empirical analysis. Economic development and cultural change, 42(3), pp.573-596.

Pesaran, H. and Shin, Y., 1999. An Autoregressive Distributed Lag Modelling Approach to Cointegration "chapter 11. In Econometrics and Economic Theory in the 20th Century: The Ragnar Frisch Centennial Symposium.

Pesaran, M.H., Shin, Y. and Smith, R.J., 2001. Bounds testing approaches to the analysis of level relationships. Journal of applied econometrics, 16(3), pp.289-326.

SADC (2004). Effectiveness and Economic Impact of Tax incentives in the SADC Region

Tanzi, V. and Zee, H.H., 2000. Tax policy for emerging markets: developing countries.

Thabani K., 2014. Review of investment incentives: Best practice in attracting investment (pp.

UNCTAD, 2014. Economic Development in Africa-Catalysing Investment for Transformative Growth in Africa.

United Nations, 2018. Design And Assessment of Tax Incentives In Developing Countries:Selected Issues And a Country Experience, CIAT, New York.

Van Parys, S. and James, S., 2010. The effectiveness of tax incentives in attracting investment: panel data evidence from the CFA Franc zone. International Tax and Public Finance, 17(4), pp.400-429.

World Development Indicators, 28(2),pp.381-400.

Zee, H.H., Stotsky, J.G. and Ley, E., 2002. Tax incentives for business investment: a primer for policy makers in developing countries. World development, 30(9), pp.1497-1516. 